\title{
ICT for Education
}

\section{A Platform for Modernization of computer science teaching methods in secondary schools in Cameroon}

\author{
Marcellin Nkenlifack1, Raoul Nangue2, Bethin Demsong3, Victor Kuate Fotso3 \\ ${ }^{1}$ LAIA - IUTFV - University of Dschang, LIMMS - National Polytechnic, Cameroon \\ ${ }^{2}$ LAIA - IUTFV of Bandjoun - University of Dschang \\ ${ }^{3}$ IUTFV of Bandjoun - University of Dschang \\ Email: marcellin.nkenlifack@gmail.com
}

\begin{abstract}
This paper presents the modeling, design and implementation of a learning platform in Cameroon. This platform contains structured knowledge acquisition modules as well as teaching, learning and assessment modules to promote a constructive learning. The objective of this project is to show how ICT can be used to improve teaching and learning with modern digital tools. This will result into enabling teaching of the official computer curriculum in secondary schools at the national level. A second objective of the project is to put in place a set of ICT based administrative and managerial tools that will guide the day-to-day activities of a secondary school. This will aid in generating informations accessible from all levels of the educational system and all its related departments and partners. This project will aim at promoting ICT accessibility in the educational system while contributing to reducing the digital divide.
\end{abstract}

Keywords-Elearning, ICT; Management Tools; Secondary school; Platform

\section{INTRODUCTION}

The new planetary economy is imposing a new type of education. Thus, the installation of platforms for the teaching of computer science in schools is not the matter of mode but it presents a quite range of advantages. This issue in tackled worldwide and researches are been carried on [1], [2], [3], [4], [5], [6], [7], [8], [9], [10], [11], [12], [13]; but the real question that raises is "which platform should be used for which pedagogy and by which pedagogues" [3] ? From studies and experiences [1], [14], [15], [16], it is clear that the interests of learners and parents is visible when teaching techniques and strategies impart not only knowledge but greatly increases chances of success in official exams. Henceforth ICT for education becomes a vital teaching and learning platform worth in secondary and high schools in Cameroon. This new method will help cultivating group work to the learners' right from childhood. It presents numerous advantages such as harmonization of official curricula nationwide, availability of statistics and decision making tools inter alia.

This project has been the focus of all education strategies in our country, be it, ministerial, national or regional. It will contribute to the consolidation of education as the target mission of the state as well as it will improve on the quality and outcomes of our education policy. The target population for this method is made up of students, teachers, teaching staffs and decision makers.

This project goes beyond professionalization of teaching learning strategies, standardization and harmonization of teaching methods as well as its evaluation to tackle areas such as:

- Providing operational pedagogic teaching tools like teacher's guides textbook, exercises for self evaluation, examination type exercises

- Providing e-learning tutorial learning or evaluation

- Providing a teaching and learning content enriching interface

- Providing at the level of the platform managerial tools for staffs.

Technical solutions are put in place in pilot schools gradually as they occur.

The issue tackled in the present article will have applications and a real impact on the development of applied research. The work is organized in six steps: We are respectively going to discuss on the context in section 2 , the methodology in section 3 , the expected results in section 4 and the perspectives in section 5 before concluding in section 6 .

\section{CONTEXT}

The non existence of a legal provision is generally the first difficulty encountered in development technology in Africa that is a lack of adequate rules and regulations. Researches have proven that there is a favorable national and international context. This can be seen through a range of legal texts meant to implement and reinforce the teaching of ICT in training schools. The focus on the institutional framework and operational input of the project discussed on the following line will enlighten us on this context.

\section{A. Institutional Framework}

- The 18th January 1996 constitution of the republic of Cameroon states that every citizen has the right to education.

- Relying on the 1995 Estates General on Education, The law $\mathrm{N}^{\circ} 98 / 004$ of 14th April 1998 states the directives of 
education in Cameroon and gives priority to basic education and new methods of teaching.

- The 27 January 2007 agreement signed between Cameroon government and an international structure (Cisco Networking Academy) emphasizes on training specialists in ICT. It states that secondary schools should provide online notes to their students; that a high frequency backbone platform on IT should be developed; that a taskforce of Network Academies should be realized. The members of this taskforce should be the representatives of the Ministries in charge of Education, those of the Ministry in charge Telecommunication, those of the Ministry in charge Research as well as international organizations such as PNUD ("programme des Nations unies pour le Développement"), UIT ("Union Internationale des Telecommunications"), FDNUF ("Fond de développement des Nations Unies pour les Femmes") and USAID.

- The decree $\mathrm{N}^{\circ}$ 2002/004 of 04th January 2002 creating in the Ministry of Secondary education (MINESEC) the general Inspectorate of Pedagogy in charge of teaching computer science in secondary schools.

- Ministerial order $N^{\circ} 3745 / \mathrm{P} / 63 / \mathrm{MINEDUC/CAB}$ of 16 th June 2003 making the teaching of computer science compulsory in secondary education.

- The directives of the Minister of Higher Education (MINESUP) assigning Universities and Internet Academies the mission of patroning secondary and high schools in mastering ICT, precisely in terms of teachers' training in computer science, defining the training curricula conform to the norm or technical assistance in multimedia centers.

- Minister of Secondary Education texts and circulars related to rules and regulations in training in computer science in Secondary and High schools in Cameroon.

\section{B. Operationnal Input of the Project}

This project will facilitate the learning process and enhance creativity to the learners. It will also give equal chances to a maximum of learners to have access to knowledge through new methods of teaching based on ICT and facilitating ipso facto their professional insertion. It intends to provide lessons based both on the rigor of international curricula and official national program of teaching computer science, on standardization and harmonization of the methods of teaching this science, the use of new forms of teaching using an interactive or multimedia technique. This technique integrates operational pedagogic teaching tools like teacher's guides textbook, exercises for self evaluation, examination type exercises; an objective type of evaluation relying on a powerful evaluation management system, a progressive content frequently updated in order to take into consideration technological development and a wide opening in terms of bibliography. Thus it requires a specified methodology.

\section{METHODOLOGY}

\section{A. Process}

Sensitization is placed on a high table in our process of putting in place this policy. It is worth for the start of the training of the target population made up of pupils, students, teachers and leaders on the interest of ICT in acquiring or transmitting knowledge and decision making in their various schools.

We have at the core of our development a platform. The implementation of this platform follows a set of steps to be followed in relation to whether the school possesses computer laboratories or not. Many referential documents related to this issue have been elaborated. We can name a few:

* For schools already equipped:

- A technical forms indicating equipments available in the school to be filled by the school,

- The leveling at the required standard of leaders

- Elaboration of a guiding plan

- Signing of an agreement the engages the two parties

- Training of main trainers and school leaders or administrators

- Implementation of the platform in the school and training of local learners

- Extension to other training domains such as science, mathematics, languages, etc...

*For non equipped schools

- Putting in place of computer science laboratory with a network

- Connection of administrative and pedagogic leaders with the network

- The following up of steps described for equipped schools as mentioned above.

\section{B. Components of the Project}

Table 1 presents the different components of the project with expected results and realization indicators as well while table 2 indicates the physical display programming of works, equipments and services concerned. 
TABLE I. COMPONENTS \& COAST OF THE PROJECT

\begin{tabular}{|c|c|c|c|}
\hline \multirow{2}{*}{$\underset{\circ}{\mathbf{N}}$} & \multirow[t]{2}{*}{ Components } & \multicolumn{2}{|r|}{ Realization } \\
\hline & & Results & Indicators \\
\hline 1 & $\begin{array}{l}\text { institutional and structural support, } \\
\text { putting in place and rehabilitation of } \\
\text { equipments, } \\
\text { training of trainers and administrators } \\
\text { recruited }\end{array}$ & $\begin{array}{l}\text { - multimedia Centers rehabilitated or } \\
\text { constructed } \\
-\quad \text { training of trainers and } \\
\text { administrators }\end{array}$ & $\begin{array}{l}\text { - Number of multimedia centers rehabilitated or constructed } \\
\text { - Number of trainers } \\
\text { - Number of platform administrators recruited and formed }\end{array}$ \\
\hline 2 & $\begin{array}{l}\text { Development of the Platform "ICT for } \\
\text { Education" } \\
\text { Development of the management } \\
\text { software called "SIGES" }\end{array}$ & 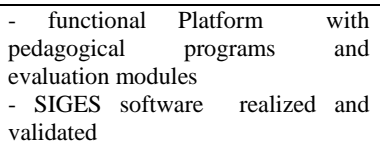 & $\begin{array}{l}\text { - Functionalities and conviviality platform } \\
\text { - Number of applicative strata offered } \\
\text { - Training on elaborated Modules } \\
\text { - SIGES software developed and delivered }\end{array}$ \\
\hline 3 & $\begin{array}{l}\text { Display, creation and permanent } \\
\text { enrichment of contents }\end{array}$ & $\begin{array}{l}\text { Basis of knowledge and Scenarii } \\
\text { created }\end{array}$ & $\begin{array}{l}\text {-number of schools } \\
\text {-Quality and number of documents and media } \\
\text {-Number of scenarii } \\
\text { - Number of tests }\end{array}$ \\
\hline 4 & $\begin{array}{l}\text { Technical and scientific research } \\
\text { projects on education applied to ICT }\end{array}$ & $\begin{array}{l}\text { Research modules to facilitate } \\
\text { teaching }\end{array}$ & $\begin{array}{l}\text {-number of research projects positively competed and } \\
\text { evaluated } \\
\text {-availability of the cooperative and piloting platform }\end{array}$ \\
\hline 5 & $\begin{array}{l}\text { Management of projects, local } \\
\text { personnel and evaluation mission } \\
\text { Consultations }\end{array}$ & $\begin{array}{l}\text { - diffusion of information and } \\
\text { management of resources } \\
\text { - missions maint for actors } \\
\text {-control and evaluation Structures }\end{array}$ & $\begin{array}{l}\text { - Diffusion of budgetary packages } \\
\text { - assessment of activities } \\
\text { - Missions defined and texts diffused } \\
\text { - Number of technical controls made }\end{array}$ \\
\hline
\end{tabular}

TABLE II. PHYSICAL PROGRAMMING OF THE PROJECT DISPLAY

\begin{tabular}{|c|c|c|c|c|c|}
\hline $\begin{array}{c}\text { Phases \& } \\
\text { works to be } \\
\text { carried on }\end{array}$ & $\mathbf{2 0 0 7 - 2 0 0 8}$ & $\mathbf{2 0 0 9}$ & $\mathbf{2 0 1 0}$ & $\mathbf{2 0 1 1 - 2 0 1 2}$ \\
\hline works & $\begin{array}{c}\text { Studies of the } \\
\text { context and } \\
\text { institutional } \\
\text { Framework }\end{array}$ & $\begin{array}{c}\text { Studies of technical and } \\
\text { organizational solutions } \\
\text { Installation of basic } \\
\text { equipments }\end{array}$ & $\begin{array}{c}\text { Display equipments and } \\
\text { solutions } \\
\text { Beginning of } \\
\text { experimentation } \\
\text { Training }\end{array}$ & $\begin{array}{c}\text { Installation of } \\
\text { equipments } \\
\text { Experimentation } \\
\text { Assessment and } \\
\text { preparation of a plan of } \\
\text { over generalization }\end{array}$ & $\begin{array}{c}\text { Installation of } \\
\text { equipments } \\
\text { Progressive } \\
\text { Generalization and } \\
\text { follow up } \\
\text { training }\end{array}$ \\
\hline Equipments & RAS & $\begin{array}{c}\text { Basic equipments for } \\
\text { development } \\
\text { Passive equipments of } \\
\text { the pilot sites }\end{array}$ & $\begin{array}{c}\text { Active equipments and } \\
\text { internet connection of } \\
\text { pilot sites }\end{array}$ & $\begin{array}{c}\text { Passive equipments of } \\
\text { other sites }\end{array}$ & $\begin{array}{c}\text { Active equipments and } \\
\text { internet connection of } \\
\text { other sites }\end{array}$ \\
\hline $\begin{array}{c}\text { Consultants/st } \\
\text { udies Services }\end{array}$ & $\begin{array}{c}\text { Studies of } \\
\text { Context and } \\
\text { institutional } \\
\text { framework }\end{array}$ & $\begin{array}{c}\text { Prior studies of } \\
\text { technical and } \\
\text { organizational solutions }\end{array}$ & $\begin{array}{c}\text { Research and realization } \\
\text { of scenarii and basic } \\
\text { modules }\end{array}$ & $\begin{array}{c}\text { Validation and feedback } \\
\text { continuation of } \\
\text { researches in other } \\
\text { modules }\end{array}$ & $\begin{array}{c}\text { Continuation of } \\
\text { development of } \\
\text { complementary modules }\end{array}$ \\
\hline
\end{tabular}

\section{Actors of the System}

The system presents five main groups or categories of actors. The table 3 that follows illustrates the role played by each group of actors.

- Teachers' role is to create evaluations and provide solutions on the platform.

- Students listen to the lectures on line and can discuss among themselves or with the lecturers.

- Leaders on their part make consultations on statistics or use the school management module, referred to by its French acronym SIGES ("Système Intégré de Gestion des Etablissements Secondaires/Supérieurs").

- The platform administrators take care of parameters and maintenance of the platform.

TABLE III. DIFFÉRENTS ACTORS OF THE SYSTEM (FROM INTRANET/INTERNET)

\begin{tabular}{|l|l|l|}
\hline Categories of actors & \multicolumn{1}{|c|}{ Activities } & \multicolumn{1}{|c|}{ Comments } \\
\hline $\begin{array}{l}\text { Teachers as producers } \\
\text { Teachers as tutors }\end{array}$ & $\begin{array}{l}\text {-pedagogical follow up } \\
\text { - Tutorial-evaluations on line } \\
\text { - putting multimedia contents } \\
\text { on line }\end{array}$ & \\
\hline $\begin{array}{l}\text { Researchers } \\
\text { developers }\end{array}$ & $\begin{array}{l}\text { - Creation/Optimization of } \\
\text { Solutions } \\
\text { - Conception of scenarii }\end{array}$ & $\begin{array}{l}\text { Project development } \\
\text { Laboratories }\end{array}$ \\
\hline Platform administrators & $\begin{array}{l}\text { Administration and } \\
\text { Maintenance of the system }\end{array}$ & $\begin{array}{l}\text { Multimedia rooms } \\
\text { (high schools and } \\
\text { colleges) }\end{array}$ \\
\hline Learners on the scene & $\begin{array}{l}\text { - follow up of lectures on line } \\
\text { - Discussion with tutors and } \\
\text { other learners }\end{array}$ & $\begin{array}{l}\text { Multimedia rooms } \\
\text { (high schools and } \\
\text { colleges or at home }\end{array}$ \\
\hline $\begin{array}{l}\text { Distants learners } \\
\text { Professionals from } \\
\text { entreprises } \\
\text { Populations and } \\
\text { Families }\end{array}$ & $\begin{array}{l}\text { - follow up of lectures on line } \\
\text { - Discussion with tutors and } \\
\text { other learners }\end{array}$ & $\begin{array}{l}\text { Offices } \\
\text { Residences } \\
\text { Cybercafés etc. }\end{array}$ \\
\hline
\end{tabular}

\section{Technologies used and global architecture}

We relied on a set of techniques and tools offered and already demonstrated by some e-learning and web service 
authors [1] [16], [6], [2], [8], [14], [7], [9]. We are putting into action a set of applications integrated in the platform called ICTE "ICT for Education". The one line teaching environment combines the two categories of tools generally found in ICTE i.e synchone and asynchone tools, notably with:

- Web access to information available such as lectures backups, Workshop sheets, Labs, numerical animations and videos

- Access to powerful tools integrated meant for collaboration, sharing and classical communication etc.

- A shared working panel, announcement space, messaging,

Our strategy is mainly based on implementation and display of applications using free softwares or open sources. This enables to put the project into practice and it guaranties:

- Secured Linux servers (level of access, FireWall, Backup)

- Development tools such as Apache-MySQL-PHP, LDAP, WebMail-IMAP-SMTP, etc...

- A files server (SMB) which secures the stockage of teachers and learners directories

- Resources are stocked in the platform based on the kernel claroline. Its code has deeply been modified in order to adapt it to our needs. These modifications include inter alia evaluation module, multiple connection on the platform, the chat, harmonization of its genuiness right away from LDAP directory whose role in to centralize in put resources, inter operability and portability cap city of the system. The platform of resources hosts various back ups on various formats.

The type of the architecture is client-server. It respects the "3-tiers" model inspired from [3], [4], [20]. The first stratum is the user interface while the second layer is the applicative stratum and the third is the data stockage layer.

The client enters in the server through the network (Intranet) using its navigator.

The lines that follow briefly present the sub-system that build up the ICT for Education system:
- The Distant Learning System : it offers a resources library to pupils and students i.e multimedia backups, exercises and didactic materials

- The Learning Management System" or SIGES: it helps learners to be registered on line, to consult their training program and their results on line, to submit and follow up the claims on their results on time, to generate automatically their documents such as school ID carte, their transcripts and school certificates, to consult any statistics on their school population and all types of infrastructures available as well as their functionalities. The SIGES system is not the concern of this article.

- The mail \& SMS system manages communication data between various actors. Messages are automatically dispatched. The documents managed by the SIGES sub-system are also transmitted by e-mail. The SMS module generates alerts sent to tutors and learners automatically. (eg: submission of a document)

- The users of the global system can use the same account to login to every service offered by ICTE. This is made possible thanks to the LDAP (Lightweight Directory Access Protocol) universal directory.

It is evident that the access and exchanges between various modules and services make use of a set of footbridge that serve as « software bus ».

\section{E. Modeling}

Our system is modeled using the UML language [17], an universal language that enables to give a model, then clearly and readably brings out the different static and dynamic elements thanks to powerful objects oriented tools or models used. We are simply going to an extract of this modelisation; details are presented by other authors [18]. Figure 1 presents the use cases diagram of platform.

We observe that a student can participate to practical works (Labs) and evaluations (quiz and exams) or can consult the notes after login the system. Similarly, a teacher can lecture, can create and organize TP and quiz. The ICT pedagogic coordinator administers the system meanwhile the school principal can consult statistics and other elements as well.

Figure 2 presents on of the sequence diagrams describing an exchange of information between actors of the system. 


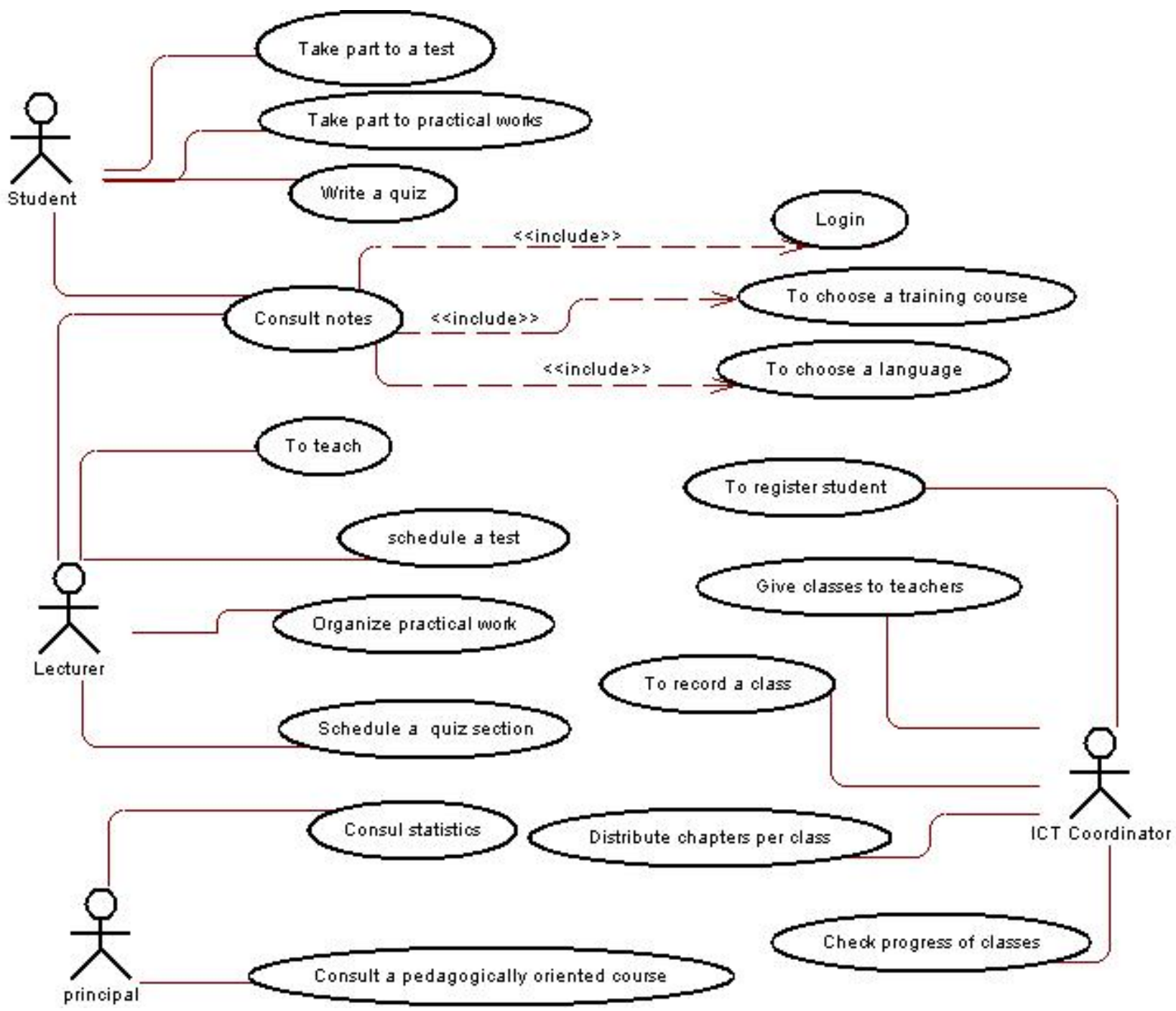

Figure 1. Use Cases Diagram of the platform

This diagram of figure 2 describes the distribution of activities between actors of the system. From the diagram, we can see that before any operation, the ICT coordinator much first of all parameter the system to open access to other actors to various the activities to be carried on. When this methodology is rigorously followed, the outcomes appear very clearly.

\section{RESUlts}

\section{A. Presentation of results}

This project which is of national scale, offers a framework of exchange and online training to our students and teachers. It enables to extend training to a larger population. It can be a possible solution to the lack of teachers in our schools. Beyond that, trainers can henceforth play their role independently to their geographical position. The technology put in place facilitates the updating of contents with a larger opening to re usage. We are gradually going to proceed through sensitization of potential target afar population via media and foldouts or initiation and implementation of school and university days dedicated to ICT.

We can point out many advantages offered by the display of ICTE, namely:

- More famous to schools using the platform

- Professionalization of trainings offered and better professional insertion of graduates since emphasis are put to practical works

- Standardization and harmonization of computer science official programs in high schools and colleges in Cameroon.

- Increase of chances of success of learners at computer science official exams

- Availability of tools for a quality control for leaders at the level of the training platform 
- Easy acquisition and maintenance of computer material through the variety of network partners

- Progressive evolvement towards the ratio of one computer for one student

- Generalization of the usage of ICT through management tools (registration, administration, library management, etc.)

- Training of 150 teachers from different schools in using ICT to teach computer science on line (1st phase of the project)

- Display of the training platform in 100 schools (1st phase)

- Production and distribution of 500000 self-learning CDROMs and DVD (1st phase) platform

- Integration of a multilingual system in the training

- Development and possession of e-learning habits to learners

- Production of operational pedagogic tools such as teaching guides, Labs, individual rehearsal exercises, evaluations, etc.

- A guarantee of the progress of contents for, they are constantly updated.

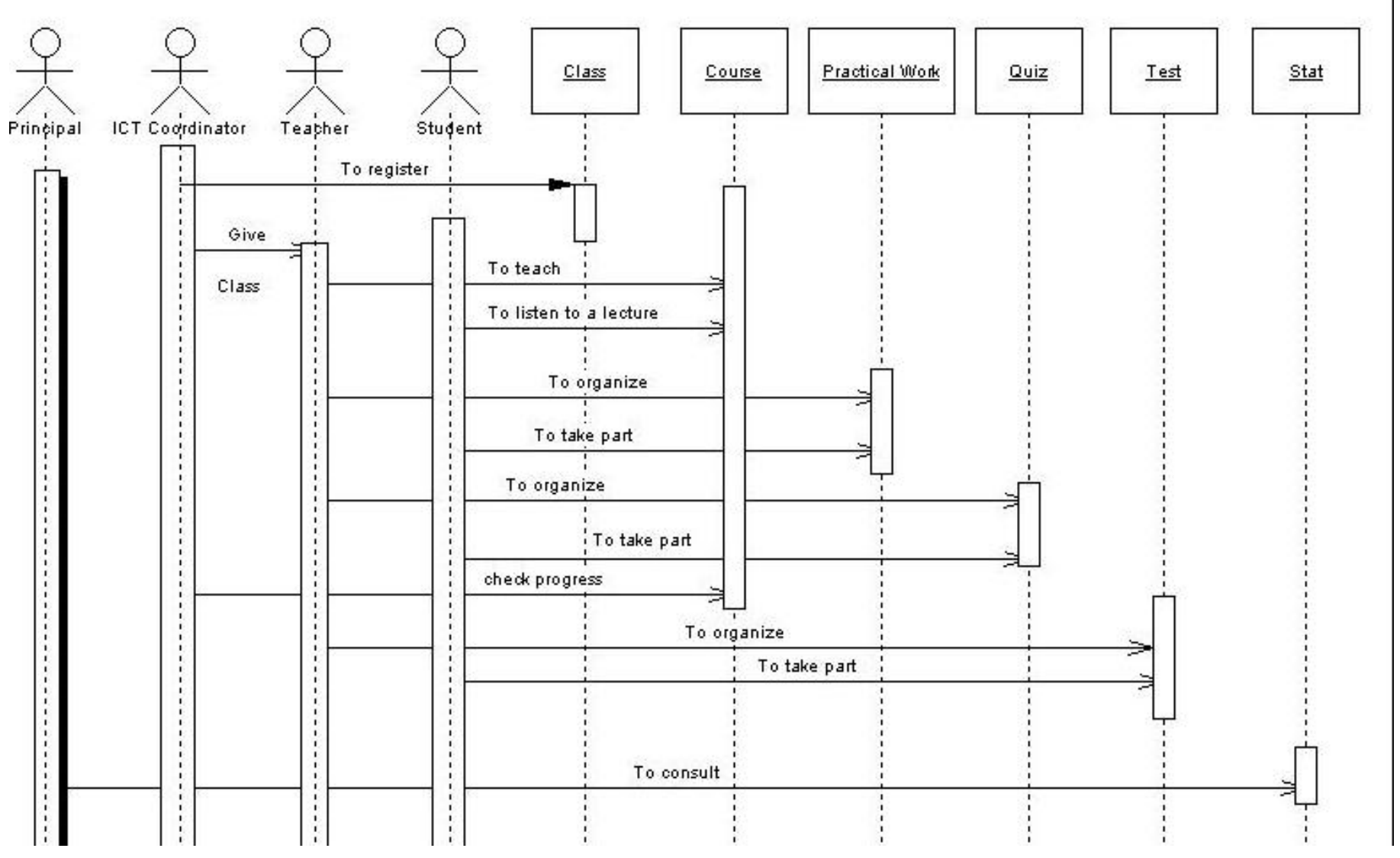

Figure 2. Sequence Diagram of activities on the platform 
Figure 3 presents one of the pages of indexes integrated in a lecture to fluctuate evaluations.

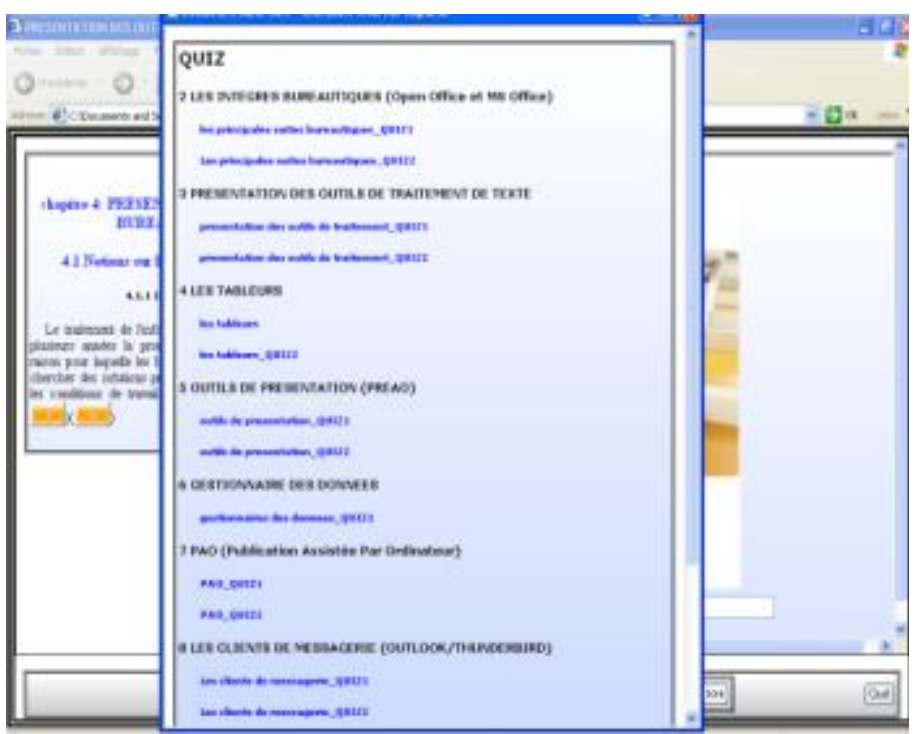

Figure 3. Page example for loading Assesment

Figure 4 is a capture of an evaluation screen in the form of a quiz in the platform. However, it is worth noticing that evaluations are many and can bare various forms.

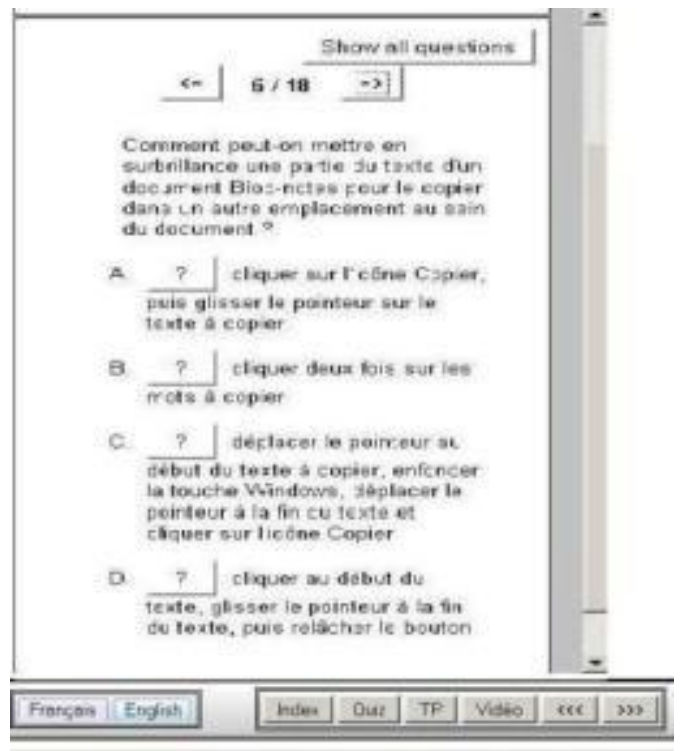

Figure 4. Example of evaluation in the form of a Quiz
The interface that presents this section of a lecture is described in figure 5 . This interface shows a section of a lecture with an image associated. The image is indicated in the text by the key " 1 ". In the right window, a click on a key (if they are many keys) enables to load the image required.

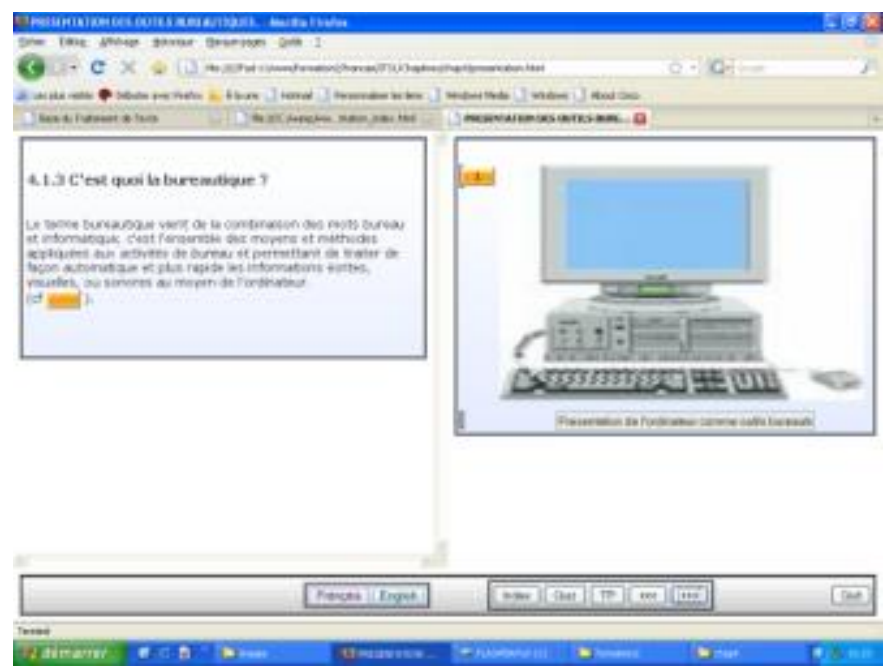

Figure 5. Example of interface for the presentation of a section of a lecture

As the management tool is concerned, we have developed the SIGES application which is a computer system based on an architecture distributed and adapted to the management of academics as well as other services via network (Intranet or Internet). As example, figure 6 shows the situation on payment of school fees for a section. This situation enables to have a global overall view of students who have paid or not at that section.

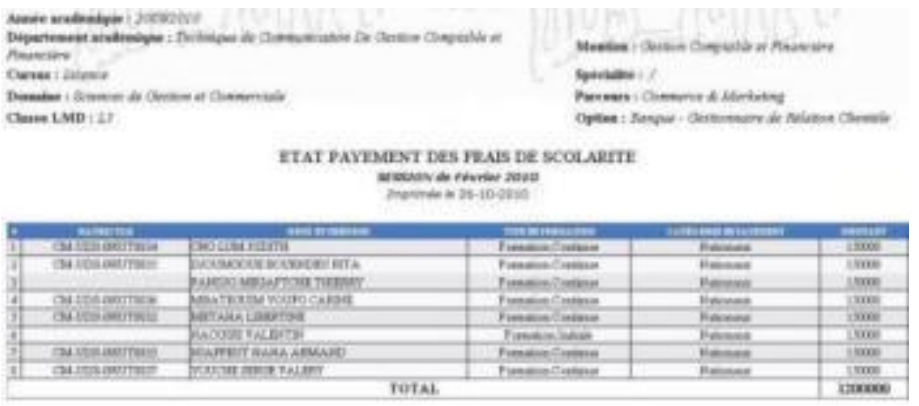

Figure 6. Example of the situation of payment of school fees after administrative registration in SIGES

The ICTE project has a number of components and should progressively be implemented all over the country in its subsequent phases.

Table 4 presents a quantity of expected outputs as well as expected results at the end of the first phase of the project. 
TABLE IV. EXPECTED OUTPUT AND EXPECTED PRODUCTS

\begin{tabular}{|c|c|c|c|c|c|}
\hline \multirow{2}{*}{$\begin{array}{c}\text { Main outputs } \\
\text { (goods or services) }\end{array}$} & \multirow[t]{2}{*}{ Quantity or Values } & \multicolumn{4}{|c|}{ Target Beneficiary } \\
\hline & & Male & Female & youth & others \\
\hline Training of trainers and leaders & 900 & 300 & 300 & 300 & \\
\hline $\begin{array}{l}\text { Training of the platform } \\
\text { administrators }\end{array}$ & 300 & 100 & 100 & 100 & \\
\hline $\begin{array}{l}\text { Production and distribution of } \\
\text { CDROMs and DVD }\end{array}$ & 500000 & 150000 & 150000 & 200000 & All the regions \\
\hline Display of the ICTE platform & $\begin{array}{l}300 \text { schools with ( } 30 \text { during } \\
\text { the first experimental) }\end{array}$ & $\begin{array}{l}\text { Total access within the } \\
\text { school }\end{array}$ & $\begin{array}{l}\text { Total access within the } \\
\text { school }\end{array}$ & $\begin{array}{l}\text { Total access within } \\
\text { the school }\end{array}$ & $\begin{array}{l}\text { And average of } 30 \text { per } \\
\text { region (high schools } \\
\text { and Colleges) }\end{array}$ \\
\hline $\begin{array}{c}\text { Realization of official piloting } \\
\text { site and administration of the } \\
\text { entire system }\end{array}$ & $\begin{array}{l}\text { Server accessible via Internet } \\
\text { or Intranets put in place } \\
\text { (Delegations, Ministries) }\end{array}$ & unlimited for leaders & unlimited for leaders & unlimited for leaders & \\
\hline $\begin{array}{l}\text { Support of research through } \\
\text { mobilization of many } \\
\text { researchers }\end{array}$ & $\begin{array}{c}\text { Many teams Planned at } \\
\text { different levels of the project }\end{array}$ & $\begin{array}{l}10 \text { researchers from } \\
\text { different disciplines in } \\
\text { ICT and Sciences of } \\
\text { education }\end{array}$ & $\begin{array}{c}5 \text { researchers from } \\
\text { different disciplines in } \\
\text { ICT and Sciences of } \\
\text { education }\end{array}$ & $\begin{array}{l}\text { 30 developers } \\
\text { And integrators }\end{array}$ & $\begin{array}{l}1 \text { team for piloting } \\
\text { and tens of } \\
\text { corresponding } \\
\text { consultants }\end{array}$ \\
\hline
\end{tabular}

As shown on table 4, the project will mobilize teams of researchers put into action to promote training of all social layers to ICT and will also contribute to the development of the country.

\section{B. Projections : Deployment in schools}

The envisaged projections of a progressive putting in place of the project in the various regions of Cameroon are presented in table 5 .

One can remark a global spread in 6 years to cover a great part of the national territory during the two years of the first phase.

TABLE V. PROJECTIONS OF DEPLOYMENT OF THE SYSTEM IN THE COUNTRY

\begin{tabular}{|c|c|c|}
\hline & Number of schools where the platform is deployed \\
\hline & & Potentiels \\
\hline October 2008 & 1 & 15 \\
\hline October 2009 & 2 & 15 \\
\hline October 2010 & 3 & 30 \\
\hline October 2011 & 10 & 45 \\
\hline October 2012 & 30 & 60 \\
\hline October 2013 & 90 & 150 \\
\hline
\end{tabular}

\section{PeRSPECTIVES AND POSSIBLE EXTENSIONS}

This project will strengthen or contribute to a better promotion of what is granted in the domain and locales predispositions towards emergency and development of technology.

Considering the techniques put in action or envisaged, the project opens new perspectives with chance of generalization of the usage of ICT through the development of a complementary management tools in other domains where the mastery of the usage of technologies displayed (health, agriculture, virtual libraries, administration, personnel and salaries, etc.).

From our experience, many perspectives are offered:
- We have started by working on physical identification of the students who can be connected to the platform and participate at evaluations through videoconference on the system. Due to the difficulties that poor countries meet because of the poor standard of bandwith. We can equally envisage a synchronous system using simplified videos. This system should make an intelligent choice of images to be posted taken them either from a data base with fixed predefined images or by making a selecting of a number of images that varies per second to make an on time light animation from a numerical camera. It is the problem of adaptation of the video flux to the bandwidth in a dynamic way. At this point, this article [10] could serve as a base.

- Considering the scarcity of teachers and the number of the students on roll that increases every day, we ought to integrate and possess the MLearning [10], [12] in order to bring closer all the actors of the system or between themselves with alerts indicating either training or tutorial ship and management.

\section{CONCLUSION}

In this article, while presenting our ICT for Education platform which is progressively taking place in Cameroon, we have intended to confirm a said [19], [21] that online teaching is inevitably an interesting solution to the problem exhibited by various traditional methods of teaching. The said platform brings a better interaction and a great number of possibilities of follow up of students independently to the time and place where the actors are situated.

Finally, this project will ensure a systematic usage of ICT to master computer science and one line teaching in a greatest number of schools and training centers in Cameroon.

Actually, related researches are normally evolving and will be the focus of our next articles. All the TDR ("Termes de Référence") and various studies considered necessary have been realized:

- Study of impact,

- Technical studies,

- Studies of risks, 
- Studies on economic impacts,

- Studies and financial programming of works (this works will not be presented in this article).

The elaboration of the remaining offer file (DAO - "Dossier d'Appel d'Offre") is on.

Concerning the progress of realization:

- Every remaining task has been planned

- Teams of correspondents are in action

- Operational teams are also in action

- Teams of trained researchers increase for, it is a matter of an important project that requires a variety of competences pluridisciplinary human resources. The results obtained are gradually integrated in the platform.

This platform is actually been used in a number of schools in the West region of Cameroon, precisely in "Government High School Baham" (http://www.cisco-ra-iutfvonline.net/LyBiBah), "Government High School Bafang", "Government High School Bayangam" and "Collège Saint Thomas de Bafoussam”. It actually enables students to:

- Personally learn their notes in computer science without needing a help of a teacher

- Self-evaluate their level of understanding by answering related questions provided by the system

- Share their knowledge with other through an integrated forum in the system

The project offers good opportunities and perspectives, namely:

- Promotion of social, human, economic and technological development

- Fight against poverty through progress using ICT and new methods of teaching

- Develop our chances of establishing our integration in the global world by reducing the gap between rich and poor countries

One of our trump cards that we play in this project is our open source softwares. They give us:

- A better Independence (technical, financial aspects, etc.)

- A great ease in displaying

- More chances in terms of security tools

- More facilities to update (GPL) the tools used

- More facilities of maintenance

With this we are convinced that this project will enable overcoming a great number of challenges in future. It will also insure a long lasting development with a mastery of ICT in the sense of the millennium development objectives.

\section{ACKNOWLEDGMENT}

This project has been conceived thanks to the expertise and support, be it direct or indirect of a number of partners and contribution of many structures already associated or to be associated to the project, notably :

- French Cooperation through the project COMETES ("Coordination et Modernisation des Etablissements Technologiques de l'Enseignement Supérieur"), since 2004

- AUF (Agence Universitaire de la Francophonie),

- PNUD (Programme des Nations Unies pour le Développement),

- MINESUP (Ministère de l'Enseignement Supérieur du Cameroun)

- MINESEC (Ministère des Enseignements Secondaires) à travers ses Délégations Régionales et Départementales

- MINRESI (Ministère de la Recherche Scientifique et Technique)

- MINPOSTEL (Ministère des Postes et

Télécommunications)

- University of Dschang

- IUTFV Bandjoun (Internet Academy)

- Research Laboratories: LIMSS (National Polytechnic), LAIA (IUTFV).

\section{REFERENCES}

[1] Nkenlifack M., Nangue R., Noulamo T. and Kwonche A. (2009), "Les TICE au service de la Formation Ouverte à Distance à l'Université de Dschang : Implémentation de SIEL (Système Intégré d'Enseignement en Ligne basé sur Internet)", Journal Langue et Communication, $\mathrm{N}^{\circ} 07$ novembre 2009, Revue scientifique internationale de recherche multidisciplinaire, ISSN 1560-3407

[2] Talla N., Tonye E., Dipanda A. and Ewoussoua L. (2010), “A model of Distance Learning of Technologies for Developing countries: Case of the Master (M2) in Telecommunications at the National Advanced School of Engineering in Cameroon", 10th African Conference on Research in Computer Science and Applied Mathematics CARI'2010, Côte d'Ivoire, Yamoussoukro, October 18 - 21, 2010

[3] Boyom S., Essome S., Takoudjou A. and Kamdem D. (2005), "Campus virtuel: exploit technologique mais pour quelle pédagogie, par quel pedagogue ?", in Akono A., Tonye E., Dipanda A., Kokou Y. (ed.), Proc. Int. Conf. On Signal \& Image Technology and Internet Based Systems, IEEE SITIS'2005, Yaounde, Cameroon, ISBN 2-9525435-0.

[4] Manlescu I., Brambilla M., Ceri S., Fraternali P. (2005), "Model Driven Design and Deployment of Service-Enabled Web Applications", ACM Transaction on Internet Technology, August 2005, Vol. 5, Number 3.

[5] Koum G., Yekel A., Tampolla S. and Sanbong T. (2005), "Vocal Interaction in Web User Interface involving natural Language Processing”, in Akono A., Tonye E., Dipanda A., Kokou Y. (ed.), Proc. Int. Conf. On Signal \& Image Technology and Internet Based Systems, IEEE SITIS'2005, Yaounde, Cameroon, ISBN 2-9525435-0.

[6] Drissi M. and Talbi M. (2009), "Dispositif de la formation à distance pour préparer les étudiants universitaires marocains à suivre des cours scientifiques en français - FOSEL (français sur objectifs spécifiques en ligne)", Revue africaine de didactique des sciences et des mathématiques, Numéro 4, 15 décembre 2009 : http://www.radisma.infodocument.php?id=687.

[7] Dahbi A., El-kamoun N. and Berraissoul A. (2009), "Conception d'un système hypermédia d'enseignement adaptatif centré sur les styles 
d'apprentissage : modèle et expérience", International Journal of Technologies in Higher Education, vol 6 (1), 2009, PP 55-71.

[8] Cacheux C. (2009), "Analyse des usages des espaces numériques de travail dans l'enseignement secondaire usages prescrits : adhesion ou resistance des usagers ?", Journal ISDM n³7-2010 spécial Numérique (s) : Défis, Enjeux et Perspectives, Actes du VIe Colloque Jeunes Chercheurs Praxiling, Montpellier, les 25 et 26 juin 2009.

[9] Kandel R. (2010), "De la conception des supports informatiques a la conception des dispositifs didactiques", Journal ISDM n³7-2010 spécial Numérique (s) : Défis, Enjeux et Perspectives, Actes du VIe Colloque Jeunes Chercheurs Praxiling, Montpellier, les 25 et 26 juin 2009.

[10] Trifonova A. and Ronchetti M. (2004), "A General Architecture of MLearning", Journal of Digital Contents, Vol. 2, Issue 1, 2004, ISSN: 1696-313X

[11] Raynaud J., Martel C., Villiot-Leclercq E., Gerbe O., Jullien J. and Camarero R. (2009), "Pour un système intégré de gestion du processus d'éducation et de formation", Revue internationale des technologies en pédagogie universitaire, vol. 6 (2-3) 2009, www.ritpu.org.

[12] Wishart J., McFarlane A. and Ramsden A. (2005), "Using Personal Digital Assistants (PDAs) with Internet Access to Support Initial Teacher Training in the UK", mLearn 2005, 4th World conference on mLearning, Cape Town, South Africa, 25 -28 October 2005. Available: http://www.mlearn.org.za/CD/papers/Wishart.pdf

[13] Assude T., Bessieres D., Combrouze D. and Loisy C. (2010), Conditions des genèses d'usage des technologies numériques dans l'éducation, Revue STICEF, Volume 17, 2010, ISSN : 1764-7223, mis en ligne le 10/072010, http://sticef.org

[14] Nkenlifack M., Nangue R., Tchokomakoua M. (2009), "Projet TICLAC : TIC pour la Modernisation de l'Enseignement des Langues et Cultures nationales dans les établissements, Conférence internationale : ASAP 2009 sur la "Diversité culturelle et Internet multilingue en Afrique", 2 au 5 décembre 2009, Hôtel Hilton, Yaoundé-Cameroun

[15] Nkenlifack M., Noulamo T. and Nangue R. (2006), "Contribution des TIC au Développement de la Formation Ouverte à Distance à l'IUT Fotso Victor de l'UDS : Déploiement de SIEL (Système Intégré d'Enseignement en Ligne basé sur Internet)", Proc Int. Conf. on Sustainable Engineering Development In Africa - African Solutions for African Problems -, June 4-8, 06, Yaounde, Cameroon.

[16] Fogue M. and Nkenlifack M. (2006), "Formation Ouverte à Distance : Nouvelle façon d'apprendre et d'enseigner, ETUDE DE CAS SUR LA DIVERSIFICATION DE L'ENSEIGNEMENT SUPÉRIEUR ET L'ADAPTATION AU MARCHÉ", Conf. Int., Thème "L'enseignement Supérieur au coeur des Stratégies de Développement en Afrique Francophone. Mieux Comprendre les Clefs du Succès", 13-15 Juin 2006, Ouagadougou, Burkina Faso http://siteresources.worldbank.org/EDUCATION/Resources/278200$1121703274255 / 1439264-$ 1137083592502/Presentation_IUT_Dschang.ppt

[17] Web site of the OMG (Object Management Group) - manuel de référence UML 2.0, //www.omg.org, (consulté en 2008).

[18] Owono A., Mbaya A., Guepi L., Kegninkeu A. and Guegang P. (2008), "Projet ICT for Education : Mise en œuvre du Curriculum ITS pour les nouvelles formes d'enseignement de l'informatique", Mémoire de fin d'études de DUT Informatique de Gestion, IUT FV de l'Université de Dschang, Cameroun, 2008.
[19] Abid-Zarrouk B. (2010), "Une analyse de l'efficacité interne des modes d'enseignements par correspondance, en présentiel et en ligne dans le cadre de la préparation au DAEU", Revue STICEF, Volume 17, 2010, ISSN : 1764-7223, mis en ligne le 19/07/2010, http://sticef.org

[20] Nkenlifack M., Noulamo T. and Nangue R. (2006), "Système Intégré d'Enseignement en Ligne basé sur Internet au service de la Formation Ouverte à Distance à l'Univ. de Dschang", Actes Conf. Int. Euro Graduation@ccess, Yde-Cameroun, 23-24 mai 2006 : http://www.eurograduation-access.org

[21] Mvoto C. (2010), "Appropriation des innovations dans les écoles normales supérieures : une étude des besoins, des avantages et contraintes de l'intégration des TIC", frantice.net, Numéro 1 - juillet 2010. Récupéré du site de la revue : http://www.frantice.netdocument.php?id=125. ISSN 2110-5324

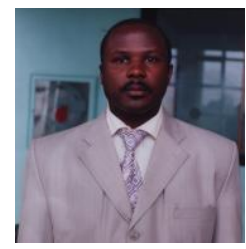

\section{AUTHORS PROFILE}

Dr. Marcellin Julius NKENLIFACK is the Head of Computer Science Department, Institute of Technology, University of Dschang, and an Associate Professor. He received M.A. degrees in Computer Science, followed by Ph.D. in Computer Engineering and Control from National Polytechnic Institute, University of Yaounde I. He had been a visiting researcher at Institut Scientifique et Polytechnique Galilee, Universite de Paris 13 (2001) and SUPELEC - Rennes, France (2003). He has published more than 20 papers in reputed International journals and Conferences in the field of Software Engineering, Computer Applications in Industry and Engineering, Object oriented Modeling and Simulation, Meta-modeling, UML, Hybrid Control Systems, Distributed Control, Computer in Education, E-learning. He has been awarded a Lecturer's award for 2003-2007 period for exceptional contributions towards developing e-learning at University of Dschang. He is an Editorial Board Member / Associate Editor / Reviewer of many internationals journals and conferences.

Raoul Calvain Nangue is teaching and researcher at Laboratory LAIA of the IUTFV of the University of Dschang. It is also Doctorant in the "Department off Information and Communication Technology, School off ICT, Nelson Mandela Metropolitan University" in South Africa.

Bethin Demsong is a Head of Service of the General Affairs, IUT Fotso Victor of the University of Dschang, Cameroun, studying with the cycle of Master in Science of the Language at the University of Dschang,Cameroun. He is a French and English Languages teacher.

Victor Kuate Fotso is working in the Data-processing Cell with the IUT Fotso Victor of the University of Dschang, it is titular of Bachelor in Computer Science and Network, and postulates with an inscription in Master in Computer Science. 